\title{
Curating the Nation: The Politics of Recognition in a Bahamian National Museum
}

\author{
Maria A. Lee \\ The George Washington University ${ }^{1}$
}

ABSTRACT

The Commonwealth of The Bahamas achieved independence in 1973, yet plans to open a national museum have not reached fruition. Drawing on this vacancy, I analyze what could be entailed in thinking about the Bahamian nation from the curatorial standpoint of a national museum. I employ a framework grounded in museum anthropology to identify specific areas that this institution might consider. In particular, I argue for engagement with the politics of recognition of multiple perspectives and heritages within the Bahamian community. While many kinds of diverse experiences can be explored, I address the opportunity to rethink race, color, and Bahamian national identity in light of an exclusionary black Bahamian rhetoric deployed in early nation-building projects from 1973 to 1992. I also explore previous African-centered curatorial frameworks in various Caribbean national museum systems to caution against this onedimensional regional trend. More broadly, I consider how a national museum of this nature could facilitate a more fluid notion of Bahamian national identity.

\section{INTRODUCTION}

National museums are implicit in the construction of national identities; and are very much implicit in the social and political agendas of the twenty-first century. In particular, narrating the nation in the museum increasingly becomes a task of narrating the diversity of the nation and for engaging in a politics of recognition (McLean, 2005, p. 1).

The Commonwealth of The Bahamas achieved its independence in 1973, yet plans to open a national museum have not reached fruition. In the Antiquities Act of 1998, an official institution named The National Museum of The Bahamas was established under the auspices of the Antiquities, Monuments, and Museums Corporation of The Bahamas (AMMC, 1998), its corporate and quasi-governmental body. Article 19 of the Act states that the National Museum was intended "to establish, operate, and administer museums throughout The Bahamas." It was also designed, among other functions, "to be the major national and public repository of all artifacts of integral importance to the prehistory,

\footnotetext{
${ }^{1}$ Maria A. Lee, M.A. Anthropology, The George Washington University, Washington, DC.

Acknowledgements: The author is grateful to the Managing Editor and two anonymous reviewers for their helpful contributions. She also thanks her advisors, Gwyneira Isaac and Kym Rice; and friends and family, particularly Nicholas Strohmayer, Gabrielle Misiewicz, and Julia Lee, for their insights and support.

The author discussed ideas from this paper at the annual meeting of the International Council of Museums International Committee for the Training of Personnel (ICOM-ICTOP) in 2015.

E-mail: maria.a.lee12@gmail.com

APA reference: Lee, M. A. (2015). Curating the nation: The politics of recognition in a Bahamian national museum. The International Journal of Bahamian Studies, 21(1), 91-107. http://dx.doi.org/ 10.15362/ijbs.v21i1.247
} 
history, and cultural development of the Bahamian people and The Bahamas." Following this mandate, AMMC officials began to operate a national museum system including two museums on the island of New Providence and others on the islands of San Salvador and Long Island. In May 2015, AMMC officials announced that three new museums would also be opened under their authority on the island of Grand Bahama (“AMMC expands”, 2015). AMMC representatives also manage the nation's monuments, forts, and other historical sites. Despite the development of this system, a centralized national museum has yet to emerge.

Statements to the public from AMMC officials since 2008 signal that plans are proceeding to convert a historic mansion in downtown Nassau into a state-of-the-art national museum (Thompson, 2008; Jones, 2012; Lightbourne, 2014). An AMMC official, however, admitted that renovations are "in a sort of limbo" (M. Pateman, Senior Archaeologist, personal communication, June 23, 2015). To be clear, it is not my intention to find fault with AMMC officials with respect to the ongoing absence of a centralized national museum. The lack of support and funding for cultural development in The Bahamas continues to be a blind spot in the infrastructure of this young nation, presenting a broader social and political problem that is too large to address here. Instead, I bring attention to the unique opportunity to critically engage a curatorial and museum anthropology grounded framework for conceptualizing this institution while it is under construction. I argue that mid-20th century political constructions of a racialized black $^{2}$

2 I deviate from racial categories of "white" and "black" as much as possible. Instead, I describe skin pigmentations of Bahamians in terms of their degree of darkness and lightness so that the reader may
Bahamian national identity could be addressed and unpacked if a national museum aims to narrate the diversity of its nation, and engage in a politics of recognition of multiple histories, identities, and perspectives. While many kinds of experiences should be curated within the museum's walls $^{3}$, this paper primarily focuses on how this institution could approach notions of race in light of the symbolic rhetoric of black Bahamian identity deployed during the nation's formative years in the latter half of the 20th century.

This analysis contributes to an emerging field that seeks to explore the national museum as a cultural institution in a range of contrasting national contexts. Specifically, national museums exist in unique environments. Therefore, to develop a curatorial framework for a national museum, contemporary theory suggests that we examine the origins, purpose, politics, and narratives of the nation (Knell, Aronssen \& Amundsen, 2014). McLean defined the challenge for curators as follows: to "narrate the diversity of the nation" by "engaging with a politics of recognition” (2005, p. 1). Macdonald further refines the framework, explaining that national museum professionals must consider "what is entailed in 'thinking' and 'doing' the nation" as well as how to share their findings with diverse publics (2012, p. 273).

In this paper, I examine the origins and political constructions of Bahamian national identity and lessons from the development of histories by pre-existing Caribbean national museums to show what the

gather the ambiguities of binary racial constructions.

3 For example, experiences of individuals from the Out Islands of the Bahamian archipelago, individuals and their descendants who have lived abroad, as well as the experiences of women, immigrants and their descendants of Greek, Chinese, or Lebanese ancestry, stateless children, and Haitian-Bahamians. 
application of contemporary museum anthropology theory might look like in the context of a centralized Bahamian national museum.

The methodology of this paper is primarily theoretical, applying contemporary practices of museum anthropology to the conceptualization of a centralized Bahamian national museum. I do so, however, in the context of archival and ethnographic research on black political discourse in The Bahamas that I conducted in the summer of 2011. In this earlier study, I reviewed specific archival sources at the National Archives of The Bahamas in Nassau, New Providence and the British National Archives at Kew in London, England that included legal records and public records such as newspapers. I also engaged in ethnographic and oral history interviews that tackled racial worldviews and personal experiences of black and non-black Bahamians on the island of New Providence. Such research included structured and unstructured interviews, surveys, and participant observation of political discourse for the purpose of triangulating the events of the late 20th century into the experiences of individuals in the present. I gathered contacts and conducted interviews and casual conversation with over 25 Bahamians aged 18 to 93 years, from a range of socioeconomic and racial backgrounds, about their Bahamian identity (Lee, 2012, p. 9). While I have included only a limited sample of this earlier research, its findings have gained new relevance and significance as I thought about a possible curatorial framework for a national museum. In the final section of this paper, I also include excerpts of an interview with an AMMC official. Beyond this interview, however, I regret that further insight could not be gained in my study by further participation of AMMC staff. When I reached out to other
AMMC staff members, two declined to be interviewed and another could not be reached for comments.

In this analysis I acknowledge the colonial legacy of museums that serving a culturally homogenous elite. I also recognize the role of such museums in perpetuating particular power relations (through labeling, categorizing, and objectifying) between ethnicities, genders, and classes, thereby largely favoring the perspective of the dominant culture. In the postmodern school of thought, museum practitioners are challenged to decolonize the museum (Lonetree, 2012; Witcomb, 2007). That is, museum practitioners should articulate more complex histories and identities in order to contribute to cultural democratization and promote social change (Bal, 2006; Golding \& Modest, 2013; Gregory \& Witcomb, 2007; Phillips, 2011; Sandell, 2007). Adopting more inclusivity and direct engagement with its diverse communities are key challenges that each national museum must overcome (Witcomb, 2007, p. 133; Kreps, 2011, p. 73; Simpson, 2001, p. $1)$. In this negotiation of historical and cultural representations of Bahamian national identity and politics of recognition within a national museum framework, it is imperative that a sensitive and inclusive curatorial policy and practice be carefully considered and implemented. Applying postmodern theory, practitioners in a Bahamian national museum could rethink the nation's darkest moments in history and ensure that the museum remains relevant to its diverse community members in the present.

A Bahamian national museum that advocates productive dialogue and collaboration among the nation's diverse population could encourage an environment that embraces and values all citizens - a position in which postmodern theory 
squarely imagines the national museum. The nation's political legacy of serving a homogenous black electorate has had lasting effects on the popular consciousness of Bahamian national belonging. Adopting this legacy within the context of a national museum would be inconsistent with the establishment of a contemporary cultural institution.

\section{Decolonizing the Political Constructions of Bahamian National Identity}

While The Commonwealth of The Bahamas has no museum to decolonize per se, the racialized ideology of Bahamian national identity could be addressed and analyzed if a national museum narrates the diversity of the nation. This process is especially significant if a national museum is to engage in a politics of recognition. Although slavery was abolished on August 1, 1834 in the British Colony of the Bahamas, little changed in the relationship of former slave owners and enslaved Africans in the post-emancipation era in the colony or elsewhere in the Caribbean (Craton \& Saunders, 1998, p. 13). The light-skinned Bahamian mercantile oligarchy, famously labeled as "Bay Street" or "Bay Street Boys" for the main street from which they dominated the capital city of Nassau on the island of New Providence, reasserted economically restrictive and politically discriminatory measures into the mid-20th century (Craton \& Saunders, 1998, p. 14). When a new political order was established in 1967 through democratic elections, government shifted for the first time to leaders with darker skin tones - like the majority of the population (Lee, 2012, p. 71). Remaining in power from 1967 through the colony's transition into independence in 1973, and until 1992, Lynden Pindling and the Progressive Liberal Party (PLP) were engaged in over thirty years of nation building.

In a previous study (2012), I looked at what forms of black political discourse took place in The Bahamas from 1967 to 1992 during the transformation of power in the mid-20th century under the leadership of Prime Minister Lynden Pindling and the PLP. I found that these state leaders demonstrated how Bahamians should view their national identity and heritage at a crucial time of political transformation and transition to nationhood. The deliberate performance and rhetoric of a unified blackness in Bahamian society, established a foundation through which popular understandings of an exclusionary black Bahamian nation were able to emerge. Political imaginings during this time and public response to it have played a central role in the construction of popular discourse about Bahamian national identity to the present-day.

Through its political propaganda of black disenfranchisement, the PLP government deliberately shaped a Bahamian national identity that was explicitly black (Hughes, 1981; Craton, 1998). For example, during the early years of the PLP's political rise to power, violent visual imagery of masterslave relationships was repeatedly represented in local newspaper cartoons (Figure 1). These cartoons allowed the PLP to provide a vivid picture of black marginalization by the elite minority that was easily digestible for literate and illiterate Bahamians alike.

In a March 1958 issue of The Nassau Herald, one of the first cartoons listed the names of representatives of the opposition using the command, "These are The Names! Remember Your Chains!” effectively equating these representatives with slave masters. Shown in Figure 1, the headline "Your Freedom Depends on How Tight Your Grip and Faith in the PLP” was also predicated on the symbolic power of slavery. Using the image entitled "Quicksand of Enslavement”, the cartoon depicted a darker- 
colored man as being endangered by the forces of "white oppression", "labour exploiters", "freedom killers”, and "negro haters" while being pulled away from such enslavement by choosing to vote PLP leaders into power. The PLP, in this propaganda piece, is depicted as the heroic figure with the power to metaphorically lift the character out of the suffocating forces of white oppression. In a new era when opposition to the Bay Street regime was being voiced politically for the first time, PLP leaders defined the party's political identity as the liberator from white power, racism, and modern-day slavery. They linked the Bahamian legacy and memory of African enslavement to socioracial inequalities in the mid-20th century (Hughes, 1981; Craton, 1998). While this linkage was - and continues to be - relevant, the effects of this comparison continue to be seen in the way many Bahamians construct their national identity through the racial distinction of black versus white. Such language, whereby non-blacks are symbolically excluded from any productive imagination of national belonging, has had negative effects on how average citizens think about their heritage and identity today (Hughes, 1981; Lee, 2012).

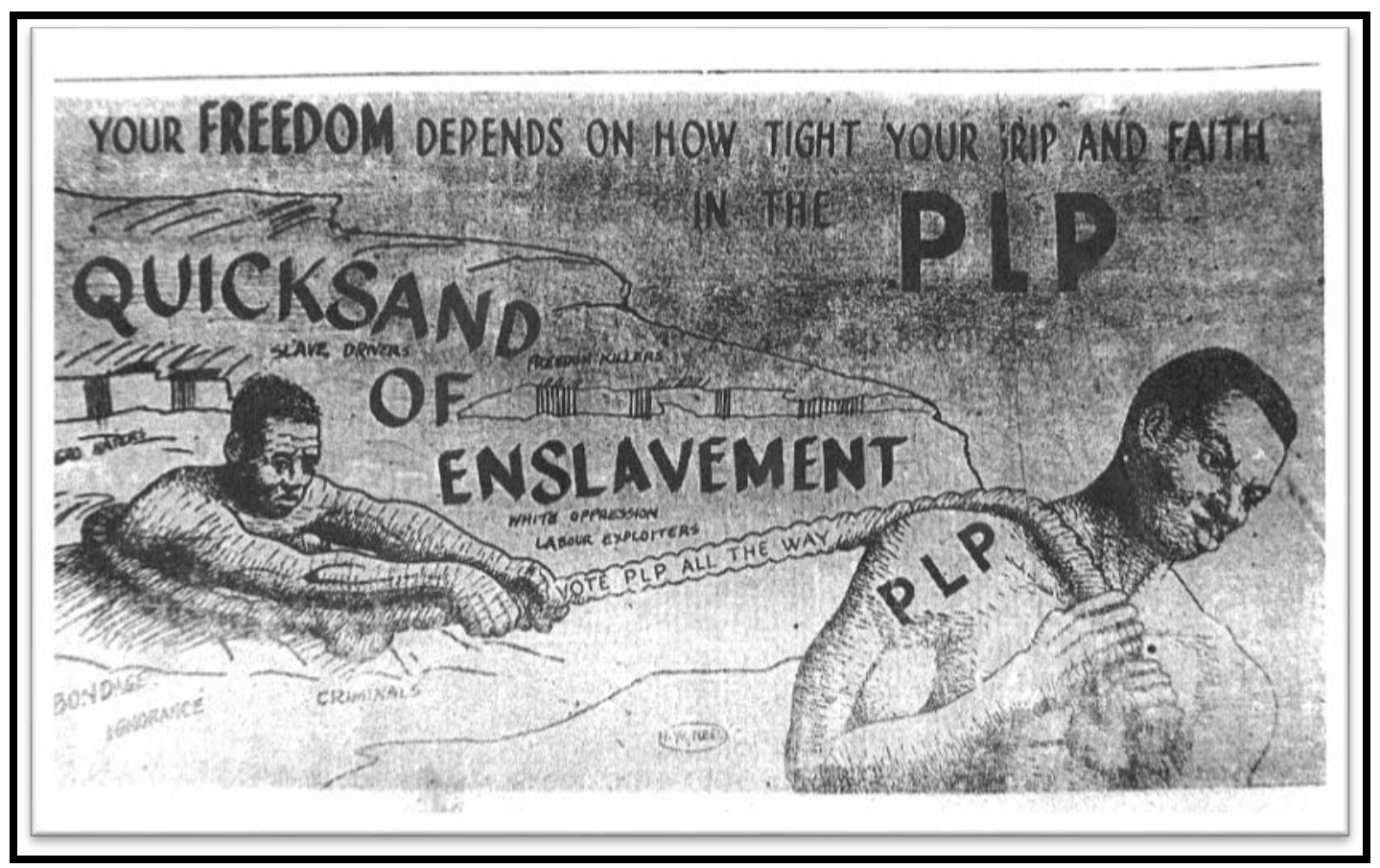

Figure 1: Your Freedom Depends on How Tight Your Grip and Faith in the PLP, Nassau Herald, September 1957, Courtesy of The National Archives of The Bahamas.

Newspaper cartoons of this nature as well as recurring audio and audiovisual broadcasts on the state-owned and monopolized radio and television network, Zephyr Nassau Sunshine (ZNS), continued to be projected by various PLP governments from 1967 to 1992, long after the PLP government had established political control (Lee, 2012, p.
70). Such broadcasts comprised film and sound-bytes from the mini-series Roots (1977). Kunta Kinte, the enslaved African protagonist in Roots, was shown being whipped with a rope made of animal hide. The biblical character, Moses, in The Ten Commandments (1956) was shown exclaiming “Let my people go!” which 
reflected the larger metaphor of Pindling as "The Black Moses" (Strachan, 2002, p. 121). When I conducted this ethnography in 2011, many Bahamians and others who were living in The Bahamas during this time had vivid memories of the content of these recordings due to their frequent and repetitive airplay. Others recalled being bussed as schoolchildren to watch consecutive episodes of Roots in the 1970s, and seeing numerous copies of both films available for purchase in local video stores. Thereby the PLP demonstrated the implicit participation of both private and public spheres in this political narrative (Lee, 2012, p. 89). The repeated symbolic political rhetoric served to remind the Bahamian electorate of what the PLP government wanted them to remember.

The motif of a master-slave relationship along with key themes of black suffering and bondage as symbols of discrimination served a dual purpose in the PLP's political projects - providing group consciousness and black solidarity to combat the Bay Street elite (Lee, 2012, p. 73). The discriminatory practices of former generations of lightcolored Bay Street elites made an inverse Bahamian black power agenda across class lines a plausible target to exploit. In fact, the former Bay Street “white” master class used legislative and economic stipulations, and property ownership to maintain their political and socioeconomic domination and marginalization of the darker colored majority (Lewis, 1968, p. 312; Craton, 1998, p. 76; Johnson, 1996, p. 17). Critically, however, the PLP government's voluminous motifs of chains and representations of the white minority as slave masters in mass media throughout the latter half of the 20th century failed to underscore key realities.

The use of repeated media campaigns of this nature inaccurately reproduced a racial dichotomy that did not represent the complexities of social, economic, and political divisions or alliances that existed within Bahamian society. Obscured by this narrative was the growth of a socially distinct middle class of intermediate shades that gained relative leverage over the darker majority through education and political franchise (Craton, 1998, p. 92; Johnson, 2006, p. 58; Saunders, 2003, p. 1). The preexistence of this middle class, from which the PLP emerged, necessitates a more complex analysis of power, privilege, and poverty within the historical foundations of Bahamian society (Weeks, 2008, pp. 102105; Craton \& Saunders, 1998, p. 107). Moreover, the emergence of various reform movements of more diverse origins exposes the power dynamics of color and class that existed. The highly publicized corruption and limited improvement in the quality of life of the darker colored majority in the decades following the PLP's emergence to power failed to provide real economic liberation of the nation's darker-colored majority (Craton \& Saunders, 1998, p. 411; Hughes, 1981, p. 194).

As discussed in my previous ethnographic findings, the superficial understanding of binary oppositions of white exploitation and black suffering through various PLP governments has had profound implications in the present (Lee, 2012; Bethel, 2003; Glinton-Meicholas, 2000). Sociocultural residues of these earlier political nationbuilding projects can be found in today's popular discourses of Bahamian national identity - in features of an exclusionary black belonging to the Bahamian nation, and the polarization of white, light-skinned, and non-black Bahamian others. As Bethel (2003) has acknowledged, "When describing oneself as a Bahamian, one either flashes one's skin colour as a badge of identity, or one defends oneself for not having that badge... for in the popular imagination, to be 
Bahamian is to be black” (para. 2). While a departure from white oligarchic rule was necessary in the transition to independent rule, the political discourse prevented a more productive and inclusive national body for Bahamians of all shades. Moreover, explaining the history of oppression within the nation through binary oppositions of white exploitation and black suffering has not accurately narrated the nuances and diversity of experiences of privilege and inequality that actually exist.

To counter this political discourse, the curatorial foundations of a centralized Bahamian national museum could explore the fluidity of racial and other imagined constructions of Bahamian national identity. Part of this endeavor would be to address the strengths and limitations of the PLP's cultural narratives of the Bahamian nation within its curatorial policy. The origins of such political constructions and popular imaginations of Bahamian national identity could be unpacked under the parameters of decolonizing museums in a postmodern framework. At the site of the nation's first national museum, there are clear benefits in exploring more nuanced understandings of Bahamian national identity. Under the parameters of decolonizing the museum, a contemporary curatorial framework could resituate past political constructions of Bahamian history and culture as subjective rather than objective. In so doing, museum practitioners would become leaders of inclusive social discourse by engaging in a politics of recognition.

\section{Learning from Pre-existing Caribbean National Museums}

The construction of a centralized national museum provides an opportunity for The Bahamas to present a unique historical and cultural narrative with insight from preexisting national museums in the Caribbean region. Here, I aim to find a middle ground that could enable an institution to narrate the diversity of the Bahamian nation within the context of current successes and challenges of relevant Caribbean national museum systems.

Cummins (2005) suggests that Caribbean history has long been expressed as an addendum to European history of the British Empire (p. 92). Much like the political narrative developed by the first Bahamian government, Cummins highlights the European/African binary to which most national museums in the Caribbean have responded:

White elites and external allies have had a virtually secure monopoly over the social and economic production of resource ownership and economic decision-making. The elite's intellectual ammunition was deployed against the African Caribbean, alienating themselves from the cultural richness and philosophical complexity of the African dimension of Caribbean heritage (2005, p. 93).

Cummins identifies that Caribbean museums have had stated goals of discovery and reclaiming their nation's African heritage from the colonial and postcolonial status quos of social and economic oppression. She chronicles this ideological shift as stimulating a "greater appreciation for the past, deeper awareness of national roots, and greater sense of identity, pride, and social conscience" since the emergence of independent Caribbean nation-states in the 1960s (2005, p. 94). African Caribbean history and culture is situated in the predominant theme of permanent exhibitions of Caribbean museums during and after the 1980s. Cummins shoulders this transition as "a greater historiographical trend towards 'peoples' history, which seeks to restore the anonymous majority of human society to 
some degree of visibility in the historical landscape” (p. 96).

While other scholarly literature on museological interpretations of Caribbean national museums is limited. Yet, Cummins' analysis is inconsistent with the practice of engaging with a politics of recognition as she suggests an African-centered curatorial frame throughout the region. Cummins' view of the transition of Caribbean national museums in representing "peoples' history" is geared towards the exclusive audience of African-descended peoples (2005, p. 96). She proposes that the histories and perspectives of descendants of enslaved Africans should be located at the forefront of both Caribbean and Bahamian museum practices. With the intent of deconstructing colonial ideologies that have served to silence enslaved Africans and their descendants or devalue blackness, Cummins' statements reflect the principal feature of decolonizing the museum. At the same time, however, she envisions a Caribbean curatorial framework that collapses the diversity of the region into a singular narrative. As an alternative, it is crucial to locate a middle ground whereby cultural institutions can rethink the darkest moments of the nation's history while also exploring how to recognize and narrate the diversity in each nation.

The distinct ways in which island nations in the Caribbean region have experienced colonialism and its effects in the present imply that there is no clear-cut formula to which Caribbean museum systems should adhere. Fernández has advised against conflating the region based on any combination of its geography, history, racial composition, or culture. He argues, "the Caribbean exceeds all possible classifications, and in fact, various Caribbeans coexist...across the entire chain of islands and territories, including the
Caribbean Diaspora” (Bailey, Cummins, Lapp, \& Thompson, 2012, p. 7). In order for a new national museum of The Bahamas to be thorough in its research of Bahamian history and culture, it must expand from a single narrative of a shared African Caribbean identity into more hybridized, multi-perspectival forms. Although many historical and cultural parallels can be drawn between The Bahamas and other Caribbean nations, Bahamian experiences and identities should not be subsumed under singular Caribbean or Bahamian identities.

As can be gleaned from the overview of Caribbean national museum systems provided by Cummins (2005), curatorial narratives attributed to blackness continue to be, with few exceptions, a regional standard (Candelario, 2007). These narratives are not solely a museological problem. Rather, they reflect a broader Caribbean consciousness of blackness as the symbol of nation-ness despite how inadequately they represent other important aspects of Caribbean and national experiences (Carnegie, 2002, p. 1). In a Bahamian, Caribbean, and global contexts, political constructions of national identity are fraught with contradictions as the marginalization of national others coincides with homogenous notions of national belonging (Carnegie, 2002, p. 1). While being careful, like Fernández, not to essentialize the diverse realities of Caribbean existence, there is a shared political thread of attributing some Caribbean national identities to a particular racialized black identity. In these instances, pre-existing viewpoints expressed by Caribbean national museums coincide with popular understandings of national identities. These institutions fail to engage with two key elements in its curatorial policy: a) the exploration of legacies of African enslavement with implications in the present-day experiences of 
marginalization and, b) privilege coupled with the recognition of diverse identities at the core of each nation's heritages.

Channeling creative ways to both present and reflect on sensitive histories of slavery and ongoing socioeconomic and cultural challenges of formerly colonized and enslaved people is a critical task for museums in the Caribbean region. An anthropologically informed museum framework could bring a refined understanding of the racial/political dynamic through a re-examination of these tightly woven racial binaries of who should or should not belong to a national imaginary. A narration of the diversity of the Bahamian nation in today's society benefits from incorporating strong themes of African enslavement, history, and culture while at the same time interrogating narratives of inclusion, recognition, and exploration of the relationship of black and non-black Bahamian others. As a more nuanced Bahamian curatorial frame is considered, blackness as a singular identifier of Bahamian identity is an obstacle that could be addressed - not sustained - within the walls of the national museum. Ultimately, popular imaginations of a black Bahamian national identity could serve as a catalyst for the museum to discuss the problems of polarizing political discourse in the legacy of Bahamian nation building.

\section{Negotiating the Past in a National Museum of The Bahamas}

The past is a powerful anchor for the construction of nationhood and notions of national belonging (Knell et al., 2014, p. 9). However, national museums have responsibilities towards negotiating a nation's past as it relates to the present most notably in dealing with its most difficult and sensitive histories in an inclusive environment of open dialogue. Linking past, present, and future national discourse is at the essence of Macdonald's (2012) question of "what is entailed in 'thinking' or 'doing' the 'nation'” (p. 289). Here, the specific question is: how could certain 21st century curatorial trends be engaged in the Bahamian context?

As Vasiliadou (2012) reveals, questions of meaning, memory, identity, and the past are unstable concepts that acquire significant importance in the postcolonial era and directly affect the role of museums. In the process of decolonizing museums, a transition is made whereby an objective notions of the nation's heritages and cultures become unraveled. As a site of learning and cultural understanding, a curatorial framework of this nature would allow for interactions with and considerations of various Bahamian publics. That is, citizens, permanent residents, immigrants, and many other individuals could not only be represented, but come together to share their own experiences in relation to the nationstate. In dealing with the past, multiple memories and perspectives need to be considered so that the national museum becomes a place of engagement - not a passive curatorial interpretation. In this framework, museum professionals benefit from engaging with the needs of diverse audiences but also in generating opportunities to empower the visitor to actively take part in the meaning-making process.

Many scholars have addressed ways in which museums can negotiate the past within a curatorial setting (Scott, 2007; Teslow, 2007; Lynch \& Alberti, 2010; Gosselin, 2011). In one instance, Lynch and Alberti advise that museums develop a "radical trust" based on the idea of collaborative engagement between community members and the museum's overall narrative or content for a specific exhibition (2010, p. 6). Inviting visitors into 
dialogue renders multiple kinds of information and memories available. Yet, as Lynch and Alberti forewarn, "radical trust may generate discensus” (p. 16) or disagreement as opposed to consensus on the museum's learning objectives and outcomes. Employing the concept of radical trust offers diverse and rewarding content for a Bahamian national museum and its negotiation with the past. At the same time, however, it would be unwise to fully disengage from more conservative practices such as the deconstruction of past political narratives in the building of the Bahamian nation. The latter is critical for the deployment of an anthropologically informed curatorial policy that allows for memories of African enslavement to be negotiated and reflected upon sensitively.

Another technique for the negotiation of the past in a Bahamian national museum setting is Gosselin's "historical thinking and meaning-making pedagogy” (2011, p. 103). Expanding on practice of radical trust, this pedagogy supports learners in learning about substantive history (presenting historical facts, main dates, events) while simultaneously engaging in procedural history (the processes involved in constructing history; Gosselin, 2011, p. 104). In the latter, she explores how curators as well as other powerful actors within communities construct history and contribute to historical thinking. Key themes serve to guide visitors through their learning experiences in the museum, while other interactive displays encourage visitors to construct their own meanings out of the ways in which the past is presented.

When considering how a Bahamian national museum could negotiate with its past, the concepts outlined above encourage introspection as well as guided learning about the diversity of Bahamian heritage and multiple perspectives of the nation's past
(Gosselin, 2011). Institutions play a significant role in the construction of personal and shared but also diverse identities (Gosselin, 2011; Rounds 2006; 2012). As "sites of memory" (Nora \& Kritzman, 1996, p. 1), national museums wield power to construct the past (and multiple memories of it) in the exhibition technologies and narratives that its staff employ. An active interplay of personal memories with those displayed within the museum is constantly taking place to a point where (re)construction of collective national memories and present-day imaginations of national belonging have the potential to take place (Vasiliadou, 2012, p. 395).

Elements of radical trust and the pedagogy of historical thinking require decisionmaking by museum practitioners in The Bahamas. When discussing the significance of sensitive histories of enslavement, postemancipation, the transition to majority rule in 1967 and the arrival of independence from Great Britain, museum practitioners have to be prepared to decide whether or not discensus is their goal or whether dissenting viewpoints among museum visitors can coexist with some degree of curatorial guidance. How and to what extent (if any) will multiple perspectives on the past and its remnants be welcomed by people visiting the museum as Bahamian nationals, residents, or visitors to the islands? What kinds of substantive histories will be chosen? What previous omissions to history will be selected and analyzed, what kind of access to primary sources will be allowed, and what kinds of differing interpretations of the same historical moments will be transposed into the exhibition space? How will these practitioners highlight the past as an unstable concept? How will previous narratives in the political constructions of the first Bahamian government be acknowledged as implicit in problematic 
discourse on who belongs (or does not belong) to the Bahamian national community? Moreover, how will the curatorial team acknowledge themselves as key players in producing their own knowledges and views of the past in the museum space?

Under contemporary museum practices, the learning outcomes of a Bahamian national museum must be open-ended. According to Rounds (2006), museums should serve as safe places to explore otherness without being forced to accept diverse experiences as personal truths. Opportunities could be afforded so that comprehensive exploration of Bahamian otherness is facilitated in a myriad of contexts. Ultimately, however, what each individual takes out of such exhibitions is relative to their own experience. Conflicting views about who does or does not belong in a museum's space or who does or does not deserve to be remembered on their own terms are to be expected (Vasiliadou, 2012). In building the curatorial framework of a national museum of The Bahamas, one cannot expect that its objectives will always match the outcomes each visitor takes away from the experience. That being said, a national museum holds immense possibility and hope that visitors may engender new outlooks on how to interact with and think about alternative Bahamian identities.

In the history of the trans-Atlantic slave trade and its present-day relevance in Bahamian identity construction, the experiences of Bahamians of African descent and those of non-black Bahamian others could be sensitively and carefully considered in this curatorial framework. Cognizant of the procedural processes that construct certain versions of history, curatorial staff could acknowledge and expose the problematic political legacy of Bahamian nation building in discussing what it means to be Bahamian. In practicing radical trust, however, this framework cannot assume full control over how individual visitors engage with (or accept) perspectives other than their own. Simon (2005) discusses a possible engagement of remembering other people's memories as visitors able to be "touched by the past" and "take other stories seriously, as matters of counsel” (p. 189). The curatorial framework should provide the opportunity for diverse publics to imagine and reflect on versions of the past other than their own. While remaining hopeful about the power of the museum's multiple narratives to reimagine what it means to be Bahamian or to belong to the Bahamian nation, it is ultimately up to each individual to accept and act upon the information presented.

\section{CONCLUSION: WHY A NATIONAL MUSEUM?}

This paper takes as its aim the identification of values involved in theorizing a curatorial framework for a centralized national museum for The Bahamas that recognizes the multiple histories and cultures of the country. As noted in post-modern literature, such a museum could provide open forms for identity building and problem-solving for communities (Lonetree, 2012; Silverman, 2010). National museums in particular serve a prominent role in building a collective national consciousness (Knell et. al, 2014). A centralized national museum in The Bahamas could become a site for unraveling longstanding political narratives and unhelpful binaries between black and nonblack Bahamians.

As Silverman writes, "museums become containers and catalysts for personal growth, relationship building, social change, and healing” (2010, p. 1). With examples of museum institutions (like the District Six Museum in Cape Town, South Africa) that have empowered and informed members of 
the community, she argues that the unique resources museums employ "perform important and essential work to benefit human relationships and, ultimately, repair the world" (Silverman, 2010, p. 2). This paper does not promise that a centralized national museum in The Bahamas will ultimately resolve problems or heal relationships within the Bahamian community. Nor does it claim that the existence of such a museum will altogether transform the ways in which Bahamians popularly imagine their national identity. It does, however, promote inclusion, recognition, and shared reflection as values that this national museum could underscore in its mission. This institution has the potential to promote the kind of personal and collective growth that can guide the Bahamian nation as it develops a new consciousness of its past and present.

In terms of racial conflict, museums can be particularly relevant as sites of social change (Archibald, 2004; Faden, 2007). Archibald (2004) proposes that older, central gathering places have become obsolete, as communities have become more fragmented in the last few decades. As opposed to commercial malls that have become meeting places for diverse members of a community, museums, according to Archibald, are better platforms of identity and meaning-making for a community. Archibald petitions those who work in the field of museums and public history to bear responsibility for community building:

Let us commit ourselves to the process of inclusion and become facilitators of public conversation about the burdens and legacies, where we resolve to overcome burdens and build upon legacies. The past is no panacea for the future but it is a place to discover what we have done well, what we have done poorly, and how we might do better
(2004, p. 11).

Curatorial staff of a Bahamian national museum could serve as facilitators for meaningful discussions of the nation's burdens and legacies regarding African enslavement, disenfranchisement, and other structural inequalities experienced by darkskinned Bahamians in the post-emancipation era. They can also become active listeners and contributors to productive discussions about including non-black Bahamian others in the popular imagining of what it means to be Bahamian. A national museum of this caliber could allow for its diverse publics to take ownership of their own narratives within the museum. This institution could also provide the opportunity for collaborative consideration of the Bahamian nation's identity politics and constructive ideas for future nation building and the politics of recognition.

Whether or not such a centralized national museum can emerge out of the AMMC remains to be seen. Admittedly, this paper does not address the nature of curatorial landscapes of the pre-existing national museum system managed by AMMC across the archipelago. This area of scholarship would bring a more comprehensive perspective on how its staff currently deals with matters of diversity and other major tenets. Additionally, it would provide insight into whether or not AMMC staff would choose to maintain these original curatorial styles or to reimagine their educational platforms in future exhibits and museums under their leadership. Without this analysis, the AMMC mandate is uncertain.

An idea of the curatorial framework being designed for the National Museum of The Bahamas can be gleaned, however, from a Nassau Guardian interview in February 2012 with AMMC's Chief Curator, Kim Outten-Stubbs, and my own interview in 
June 2015 with Senior Archaeologist, Michael Pateman. Outten-Stubbs acknowledged:

We do not have a place where Bahamian history and culture are showcased at this point in our development and history. The need is more than great. One of the most important reasons for a national museum is to look at Bahamian identity - to help us develop pride in who we are, particularly the younger people who [may not] know our stories and histories (Farmer, 2012).

Outten-Stubbs recognizes the need for a centralized museum. She sees this site as a medium to explore Bahamian identity and convey national pride particularly in the younger generation. Outten-Stubbs's description aligns considerably with the possible curatorial framework outlined in this paper. It can be hoped that her platform can also integrate multiple perspectives and diverse stories and histories. In the interview, Farmer (2012) further noted, "[the National Museum] will be communityformed, community driven, and community supported, ensuring it warmly welcomes Bahamians and takes into consideration the concerns of the people in the nation as they start the long process of forming such space."

Again, it appears that Outten-Stubbs is conscious of the need to design a curatorial framework that, to a considerable degree, fits what has been described in this paper. The dedication to ensuring community participation implies that the curatorial framework could include diverse - and even contradictory - histories within the walls of the museum.

When I asked Pateman to explain critical learning components that are a part of the AMMC's mandate to preserve and promote
Bahamian history culture, he highlighted the importance of authenticity:

The fundamental issue that we keep to the forefront with all of our education and interpretative experiences is to tell an authentic 'true' story. We do not believe in altering the story to tell the story we believe the guest or local visitor wants to hear. (personal communication, June 23, 2015)

In some respects, Pateman's response supports the use of substantive history though, in describing AMMC's educational programming, it lacks the commitment simultaneously to engage with aspects of procedural history. While aspects of substantive history are important, the processes involved in constructing history require sensitivity and acknowledgement of different, subjective experiences of the past. Without further comment from Pateman or other AMMC officials, it is unknown whether procedural history will be included in conceptualizing a national museum for The Bahamas.

According to Aronsson (2014), curatorial teams of national museums often adhere to strategies of loyalty to the contemporary political context and its preexisting constructions of national heritage. Aligned with mainstream political narratives, this strategy of loyalty involves limited engagement with multiple versions of history and heritages. This strategy also involves the representation of historical events as natural or objective according to official state narratives. As the early foundations of the Bahamian nation involved a deep-seated ideology of how various black and non-black populations should be brought within the scope of Bahamian belonging, loyalty to this narrative could remain a significant obstacle to the museum's engagement with a politics 
of recognition. In view of the team's close administrative ties to the Bahamian government, it is unknown how an exploration of these earlier political constructions would be received.

Aronsson (2014) describes curatorial teams of national museums as often adhering to 'strategies of exit', that is, choosing to remain silent on certain moments in history or present-day issues in their exhibitions in order to protect the national government of any perceived wrongdoings. It is unlikely that there will be silence on the history of enslavement of Africans or the current implications for African-descended Bahamians of patterns of discrimination in the colony's post-emancipation era. A curatorial framework of silence, however, would reflect loyalty to previous political narratives. As we progress towards a centralized national museum, I am hopeful that the cornerstone of curatorial policy will involve a nuanced analysis and celebration of diverse Bahamian narratives.

A curatorial framework that grounds its narrative on the diversity of the Bahamian nation is, of course, much easier to implement in theory than in practice. With the nation's legacy of racially polarizing political constructions, the task of providing a more inclusive framework will prove to be an immense undertaking. Nevertheless, Bahamian national identity politics can be open-ended, allowing for a more complex integration of the negotiation of knowledge and the politics of recognition than has previously been provided.

A national museum of The Bahamas provides an exceptional opportunity to grapple with what it means to belong to the Bahamian nation. In compliance with recent ethical trends in museum anthropology to decolonize museum institutions, however, a potential national museum of The Bahamas and its curatorial staff are responsible for undoing previous political discourse that has oversimplified the make-up of the Bahamian national community. The choice of how to represent certain moments in history, including eras of slavery and postemancipation, and political constructions of the nation's first government, necessitates observation by anthropologists, other cultural professionals, and average citizens alike. Representing a more fluid Bahamian national identity and giving voice to its diverse experiences is paramount. In the words of Caribbean historian Stuart Hall (1995), "Identity is not in the past to be found, but in the future to be constructed" (p. 14).

\section{REFERENCES}

AMMC expands second city historic offerings. (2015, May 12). The Nassau Guardian. Retrieved from http://www.thenassauguardian.com/news/5 6063-ammc-expands-second-city-historicofferings

Antiquities, Monuments and Museum Act. Chapter 51, Bahamas, 1998. Retrieved from http://laws.bahamas.gov.bs/cms/images/LE
GISLATION/PRINCIPAL/1998/19980005/AntiquitiesMonumentsandMuseumA ct_1.pdf

Archibald, R. R. (2004). The new town square: Museums and communities in transition. Walnut Creek, CA: AltaMira Press.

Aronsson, P. (2014). Explaining national museums. In S. J. Knell, P. Aronsson \& A. B. Amundsen (Eds.), National museums: 
New studies from around the world (pp. 29-54). Abingdon, England: Routledge.

Bailey, D. A., Cummins, A., Lapp, A., \& Thompson A. (Eds.). (2012). Curating in the Caribbean. Berlin: The Green Box. Retrieved from http://www.artesur.org/wpcontent/uploads/2012/08/CuratingintheCari bbean_Brebion.pdf

Bal, M. (2006). Exposing the public. In S. Macdonald (Ed.), A companion to museum studies (pp. 525-542). Oxford, Eng.: Blackwell. http://dx.doi.org/10.1002/9780470996836. ch32

Bethel, N. (2003, May 26). On being Bahamian. [Web log post]. Retrieved from http://nicobethel.net/blogworld/2003/05/on -being-bahamian/

Candelario, G. E. B. (2007). Black behind the ears: Dominican racial identity from museums to beauty shops. Durham, NC: Duke University Press.

Carnegie, C. V. (2002). Postnationalism prefigured: Caribbean borderlands. Piscataway, NJ: Rutgers University Press.

Craton, M. (1998). Bay Street, black power and the conchy joes: Race and class in the colony and Commonwealth of The Bahamas, 1850-2000. In H. Johnson \& K. $\mathrm{S}$. Watson (Eds.), The white minority in the Caribbean (pp. 71-94). Kingston, Jamaica: Ian Randle.

Craton, M., \& Saunders, G. (1998). Islanders in the stream: A history of the Bahamian people. Vol. 2: From the ending of slavery to the twenty-first century. Athens: University of Georgia Press.

Cummins, A. (2005). Making histories of African Caribbeans. In G. Kavanagh (Ed.), Making histories in museums (pp. 93-104). London: Bloomsbury Publishing.
DeMille, C. B. (Producer, Director). (1956). The ten commandments [Motion picture]. Los Angeles, CA: Paramount Pictures.

Faden, R. (2007). Museums and race: Living up to the public trust. Museums \& Social Issues, 2(1) 77-88. http://dx.doi.org/10.1179/msi.2007.2.1.77

Farmer, S. (2012, February 18). A national museum for the people: AMMC hosts concert to raise funds for national museum. The Nassau Guardian. Retrieved from http://www.thenassauguardian.com/index.p hp?option=com_content\&view=article\&id =24398: a-national-museum-for-thepeople \&catid=38:arts-aculture\&Itemid= 59

Glinton-Meicholas, P. (2000). Uncovering the Bahamian self. Yinna: Journal of the Bahamas Association for Cultural Studies (BACUS), 1, 104-110.

Golding, V., \& Modest, V. (2013). Museums and communities: Curators, collections, collaboration. London: Bloomsbury.

Gosselin, V. (2011). Historical thinking in the museum: Open to interpretation. In P. Clark (Ed.), New possibilities for the past: Shaping history education in Canada (pp. 245-263). Vancouver: UBC Press.

Gregory, K., \& Witcomb, A. (2007). Beyond nostalgia: The role of affect in generating historical understanding at heritage sites. In S. J. Knell, S. Macleod, \& S. E. R. Watson (Eds.), Museum Revolutions (pp. 263-275). London: Routledge.

Hall, S. (1995). Negotiating Caribbean identities. New Left Review, 209, 3-14.

Retrieved from http://newleftreview.org/static/assets/archi ve/pdf/NLR20501.pdf

Hughes, C. A. (1981). Race and politics in the Bahamas. New York: St. Martin's Press.

Johnson, H. (1996). The Bahamas from 
slavery to servitude, 1783-1933.

Gainesville: University Press of Florida.

Johnson, W. B. (2006). Post-emancipation race relations in the Bahamas. Gainesville: University Press of Florida.

Jones, R. (2012, February 1). AMMC seeking funds to raise funds to restore future home of national museum. The Nassau

Guardian. Retrieved from http://www.thenassauguardian.com/index.p hp?option=com_content\&id=23054:ammcseeking-to-raise-funds-to-restore-futurehome-of-national-museum\&Itemid=27

Knell, S. J., Aronsson, P., \& Amundsen, A. B. (Eds.). (2014). National museums: New studies from around the world. Abingdon, England: Routledge.

Kreps, C. (2011). Changing the rules of the road: Post-colonialism and the new ethics of museum anthropology. In J. Marstine (Ed.), The Routledge companion to museum ethics: Redefining ethics for the twenty-first century museum (pp. 70-84). Abingdon, England: Routledge.

Lee, M. A. (2012). Black Bahamas: Political constructions of Bahamian national identity (Unpublished honors thesis). University of Richmond, Virginia. Retrieved from http://scholarship.richmond.edu/cgi/viewco ntent.cgi?article $=1065 \&$ context $=$ honorstheses

Lewis, G. K. (1968). The growth of the modern West Indies. New York: Monthly Review Press.

Lightbourne, S. (2014, February 3). Collins mansion museum to cost nearly $\$ 14 \mathrm{~m}$. The Bahamas Journal. Retrieved from http://jonesbahamas.com/collins-mansionmuseum-to-cost-nearly-14m/

Lonetree, A. (2012). Decolonizing museums: Representing Native America in national and tribal museums. Chapel Hill: University of North Carolina Press.

Lynch, B. T., \& Alberti, S. J. (2010). Legacies of prejudice: Racism, co-production and radical trust in the museum. Museum Management and Curatorship, 25(1), 1335. http://dx.doi.org/10.1080/09647770903529 061

Macdonald, S. J. (2012). Museums, national, postnational and transcultural identities. In B. M. Carbondell (Ed.), Museum studies: An anthology of contexts (2nd ed., pp. 273286). Malden, MA: Blackwell Publishing.

McLean, F. (2005). Museums and national identity [Editorial]. Museum and society, 3(1), 1-4. Retrieved from http://www2.leicester.ac.uk/departments/m useumstudies/museumsociety/documents/v olumes/guestedit.pdf

Nora, P., \& Kritzman, L. D. (Eds.). (1996). Realms of memory: Rethinking the French past: Vol. 1 Conflicts and divisions. New York: Columbia University Press.

Phillips, R. B. (2011). Museum pieces: Toward the indigenization of Canadian museums. Montreal: McGill-Queen’s University Press.

Rounds, J. (2006). Doing identity work in museums. Curator: The Museum Journal, 49(2), 133-150.

http://dx.doi.org/10.1111/j.21516952.2006.tb00208.x

Rounds, J. (2012). The museum and its relationships as a loosely coupled system. Curator: The Museum Journal, 55(4), 413434. http://dx.doi.org/10.1111/j.21516952.2012.00166.x

Sandell, R. (2007). Museums, prejudice, and the reframing of difference. New York, NY: Routledge.

Saunders, G. (2003). Bahamian society after 
emancipation. Kingston, Jamaica: Ian Randle.

Scott, M. (2007). Rethinking evolution in the museum: Envisioning African origins. New York, NY: Routledge.

Silverman, L. H. (2010). The social work of museums. Abingdon, England: Routledge.

Simon, R. I. (2005). The touch of the past: Remembrance, learning, and ethics. New York: Palgrave Macmillan.

Simpson, M. G. (2001). Making representations: Museums in the postColonial era. Abingdon, England: Routledge.

Strachan, I. G. (2002). Paradise and plantation: Tourism and culture in the Anglophone Caribbean. Charlottesville: University of Virginia Press.

Teslow, T. (2007). A troubled legacy: Making and unmaking race in the museum. Museums \& Social Issues, 2(1), 11-44. http://dx.doi.org/10.1179/msi.2007.2.1.11

Thompson, L. (2008, February 15). Collins House to be transformed into a national museum. Thebahamasweekly.com. Retrieved from http://www.thebahamasweekly.com/publis h/bis-newsupdates/Collins_House_to_be_Transforme d_into_a_National_Museum.shtml

Vasiliadou, X. (2012). Using myth for enhancing cultural identity in the museum: case study research in Greece. Museum Management and Curatorship, 27(4), 393411. http://dx.doi.org/10.1080/09647775 .2012.720187

Weeks, D. G. (2008). Movement of the people: The relationship between black consciousness movements, race, and class in the Caribbean. (Unpublished master's thesis). University of South Florida, St. Petersburg. Retrieved from http://scholarcommons.usf.edu/etd/560/

Witcomb, A. (2007). 'A place for all of us?' Museums and communities. In S. Watson (Ed.) Museums and their communities (pp. 133-156). New York, NY: Routledge.

Wolper, D. L (Producer), \& Blinn, W. (Director). (1977). Roots [Motion picture]. Burbank, CA: Warner Bros. Television.

Your freedom depends on how tight your grip and faith in the PLP. [Cartoon]. (1957, September 28). Nassau Herald. 